\title{
KNOWLEDGE AND UTILIZATION OF INFORMATION AND COMMUNICATION TECHNOLOGY TOOLS AMONG SUGARCANE FARMERS IN ERODE DISTRICT

\author{
BOR G. $\mathrm{K}^{1}$, KALAIVANI. $\mathrm{S}^{2}$, BALASUBRAMANIAM. $\mathrm{P}^{3}$ \& BALAJI. $\mathrm{P}^{4}$ \\ ${ }^{1}$ Scholar, Department of Agricultural Extension and Rural Sociology, Tamil Nadu Agricultural University, India \\ ${ }^{2}$ Associate Professor, Department of Agricultural Extension and Rural sociology, TNAU, India \\ ${ }^{3}$ Professor \& Head, Department of Agricultural Extension and Rural Sociology, TNAU, India \\ ${ }^{4}$ Assistant Professor, Department of Agricultural and Rural Management, TNAU, India
}

\begin{abstract}
Information and communication technologies (ICTs) have become a better option for dissemination of agricultural technologies due to inadequate extension personnel. This study examined extent of knowledge and utilization of ICT tools among sugarcane farmers in Sathyamangalam and Thukkanaickanpalayam blocks in Erode district, India. A total of 120 farmers were involved in the study. Finding revealed that most of the farmers were male in the old age group with relatively good education and income. Crop farming was the sole occupation for most of the farmers who had more than 20 years of farming experience and cultivated sugarcane in over 5 acres of land. The farmers had medium level of mass media exposure, contact with extension agency and awareness of ICT tools. Television and Mobile phone were major information sources for weather forecast, land preparation and crop management and protection as compared to radio, Facebook, Whatsapp and YouTube. Strong and positive correlation existed between educational status, experience in sugarcane cultivation, contact with extension agency, information seeking behaviour and awareness on ICT tools with utilization of ICT Tools while age showed negative relationship. Generally, farmers in the study area had fairly good knowledge and utilization of ICT tools. However, major constraints in utilization of ICT tools were lack of trainings to handle the tools coupled with lack of local repair facilities/centres. The suggested intervention measure was establishment of local repair centers and capacity building of farmers.
\end{abstract}

KEYWORDS: Information, Communication, Technology, Sugarcane Farmer \& Extension service

Received: Apr 21, 2020; Accepted: May 12, 2020; Published: Jun 02, 2020; Paper Id.: IJASRJUN202010

\section{INTRODUCTION}

Agriculture is an information intensive sector (Nenna, 2014) and knowledge plays a significant role in enhancing increased productivity in the sector. However, the conventional agricultural extension system in the country has been unable to effectively and efficiently deliver timely and situation specific agricultural technologies to farmers (Anushree et al, 2018). Consequently, integrating information and communication technology (ICT) in transfer of sugarcane production technologies can help to improve productivity and quality. This approach has much more opportunity and plays a key role in enhancing and improving information flow and coverage from source to clientele (Khushboo et al, 2018).

Information and communication technology is a broader term that comprises computer hardware and software; digital broadcast and telecommunication technologies in addition to electronic information repositories (Rasheed et al, 2019). ICTs have potential to reduce digital divide and makes it possible for information to reach 
the poorest of the poor, those with limited or without access to land and other assets as well as addressing gender information disparity among women and men (FAO, 2017). The Central and State governments in India have progressively created enabling policies and infrastructure to promote and leverage the utilization of ICTs in agricultural extension services (Ramachandra, 2018).

Due to the significant role of ICTs in transfer of sugarcane technologies, this study examined farmers' knowledge and utilization of ICT tools, in order to establish the extent of use, merits, drawbacks and suggestion for improvements. This was compelling in the awake of declining sugarcane productivity, widening ratio of extension officers to farmers and the shift of farmers orientation from production focused based farming to market led and commercial focus that aims to increase productivity and income in line with Government's doubling farmer's income by 2023 initiative. The objectives of the study were:

- To examine the profile of Sugarcane farmers in Erode District

- To assess the extent of knowledge and utilization of ICT tools by the sugarcane farmers

- To examine the relationship of the profile of the sugarcane farmers and utilization of ICT tools

- To find out constraints faced by sugarcane farmers in the utilization of ICT tools and suggestions for effective use

\section{MATERIALS AND METHODS}

The Study adopted an Ex-post facto research design and was conducted in Erode district due to its vast area under sugarcane, where Sathyamangalam (Sathy) and Thukkanaickanpalayam (T.N Palayam) blocks were randomly selected. Sathy block falls under the jurisdiction of Bannari Amman sugar milling zone while T.N Palayam falls in Sakthi Sugar milling zone. The two blocks are characterized by dry climate and the soils are red loam and sandy which favours crop production. According to 2011 census, Sathy block has a population of 95,467 people and an area of 96,320 hectares while T.N Palayam block has a population of 51,072 people and an area of 18,446 hectares. Other than sugarcane, farmers in the two blocks grow crops like cassava, coconut, flowers, groundnut, maize, marigold, millet, paddy, spices, turmeric, tobacco and vegetables.

The study involved 120 farmers, who were randomly selected from four villages in each block with vast areas under sugarcane. In Sathy block, the villages were Alathukampai, Malaiadipudur, Palayakalaiyanur and Pudukalaiyanur and in T.N Palayam, Arakkankottai Gramam, Kanakkampalayam, Perumugai and Vaniputhur were selected.

Primary data formed the basis of this study and was gathered by use of an interview schedule, which was pretested in a non-study area to improve on its validity and reliability. The author physically visited farmers in their farms with the assistance of Bannari Amman and Sakthi Sugars limited officials.

Awareness on ICT tools was assessed by listing 24 common ICT tools and respondents were asked to tick either "Yes" for awareness and "No" for lack of awareness. Yes attracted a score of two and one for No. Knowledge was examined on a three point continuum scale with scores of 3, 2 and 1 for perfect, partial and least knowledge respectively. Utilization was assessed on a 6 point continuum scale of daily, weekly, fortnightly, monthly, rarely and never with scores of 6,5,4,3,2, and 1 respectively. ICTs tools useful for weather forecast information, land preparation, crop management \& protection and marketing services were listed and farmers' response sought. The data collected was processed, tabulated and analyzed with the help of Statistical Package for the Social Sciences software (SPSS) to determine frequency, 
percentage, mean, standard deviation, correlation and multiple regressions.

\section{RESULTS AND DISCUSSIONS}

The results are summarized under the sub headings of Profile characteristics of farmers, knowledge and utilization of ICT tools, relationship of profile characteristics and utilization of ICT tools, constraints and suggestions for improvements. The profile characteristic of the farmers is summarized in Table 1.

Table 1: Profile Characteristics of Farmers $\quad(n=120)$

\begin{tabular}{|c|c|c|c|c|}
\hline $\begin{array}{l}\text { SI. } \\
\text { No. }\end{array}$ & Variable & Category & Number & Percentage $(\%)$ \\
\hline 1 & Age & $\begin{array}{l}\text { Young (Up to } 35 \text { years) } \\
\text { Middle (36-45 years) } \\
\text { Old (above } 46 \text { years) }\end{array}$ & $\begin{array}{l}10 \\
23 \\
87\end{array}$ & $\begin{array}{l}8.3 \\
19.2 \\
72.5\end{array}$ \\
\hline 2 & Educational status & $\begin{array}{l}\text { Illiterate } \\
\text { Functionally illiterate } \\
\text { Primary Education } \\
\text { Middle Education } \\
\text { Secondary Education } \\
\text { Higher secondary } \\
\text { College/University }\end{array}$ & $\begin{array}{c}11 \\
8 \\
31 \\
12 \\
12 \\
12 \\
34\end{array}$ & $\begin{array}{c}9.2 \\
6.7 \\
25.8 \\
10.0 \\
10.0 \\
10.0 \\
28.3\end{array}$ \\
\hline 3 & Occupational status & $\begin{array}{l}\text { Agriculture only } \\
\text { Agriculture + Allied activities } \\
\text { Agriculture +Business } \\
\text { Agriculture + Government/private service }\end{array}$ & $\begin{array}{c}106 \\
4 \\
2 \\
8 \\
\end{array}$ & $\begin{array}{l}88.3 \\
3.3 \\
1.7 \\
6.7 \\
\end{array}$ \\
\hline 4 & Annual income & $\begin{array}{l}\text { Less than Rupees } 50,000 \\
51,001-1,00,000 \text { rupees } \\
\text { Above } 1,00,000 \text { rupees }\end{array}$ & $\begin{array}{c}2 \\
20 \\
98\end{array}$ & $\begin{array}{l}1.7 \\
16.7 \\
81.6\end{array}$ \\
\hline 5 & Size of land holding & $\begin{array}{l}\text { Marginal farmer (up to } 2.5 \text { acre) } \\
\text { Small scale farmer }(2.51-5.00) \\
\text { Medium scale farmer }(5.01-10) \\
\text { Large scale farmer(>10) }\end{array}$ & $\begin{array}{l}20 \\
40 \\
32 \\
28\end{array}$ & $\begin{array}{l}16.7 \\
33.3 \\
26.7 \\
23.3\end{array}$ \\
\hline 6 & Farming experience & $\begin{array}{l}\text { Up to } 10 \text { years } \\
11-20 \text { years } \\
>20\end{array}$ & $\begin{array}{l}18 \\
11 \\
91\end{array}$ & $\begin{array}{c}15.0 \\
9.2 \\
75.8\end{array}$ \\
\hline 7 & Area under sugarcane & $\begin{array}{l}\text { Up to } 2.5 \text { acres } \\
2.51-5.0 \text { acres } \\
>5.0 \text { acres }\end{array}$ & $\begin{array}{c}7 \\
41 \\
72\end{array}$ & $\begin{array}{l}4.8 \\
34.2 \\
61.0\end{array}$ \\
\hline 8 & Experience in sugarcane cultivation & $\begin{array}{l}\text { Up to } 5 \text { years } \\
5-10 \text { years } \\
>10 \text { years }\end{array}$ & $\begin{array}{l}18 \\
11 \\
91\end{array}$ & $\begin{array}{c}15.0 \\
9.2 \\
75.8\end{array}$ \\
\hline 9 & Social participation & $\begin{array}{l}\text { Low } \\
\text { Medium } \\
\text { High }\end{array}$ & $\begin{array}{l}18 \\
75 \\
27\end{array}$ & $\begin{array}{l}15.0 \\
62.5 \\
22.5\end{array}$ \\
\hline 10 & Mass media exposure & $\begin{array}{l}\text { Low } \\
\text { Medium } \\
\text { High }\end{array}$ & $\begin{array}{l}23 \\
67 \\
30\end{array}$ & $\begin{array}{l}19.2 \\
55.8 \\
25.0\end{array}$ \\
\hline 11 & Contact with extension agency & $\begin{array}{l}\text { Low } \\
\text { Medium } \\
\text { High }\end{array}$ & $\begin{array}{l}11 \\
83 \\
26\end{array}$ & $\begin{array}{l}9.2 \\
69.2 \\
21.6\end{array}$ \\
\hline 12 & Training undergone & $\begin{array}{l}\text { Low } \\
\text { Medium } \\
\text { High }\end{array}$ & $\begin{array}{l}52 \\
51 \\
17\end{array}$ & $\begin{array}{l}43.3 \\
42.5 \\
14.2\end{array}$ \\
\hline 13 & Information seeking behaviour & $\begin{array}{l}\text { Low } \\
\text { Medium } \\
\text { High }\end{array}$ & $\begin{array}{l}20 \\
81 \\
19 \\
\end{array}$ & $\begin{array}{l}16.7 \\
67.5 \\
15.8 \\
\end{array}$ \\
\hline 14 & Innovativeness & Low & 23 & 19.2 \\
\hline
\end{tabular}




\begin{tabular}{|c|c|c|c|c|}
\hline & & $\begin{array}{l}\text { Medium } \\
\text { High }\end{array}$ & $\begin{array}{l}76 \\
21\end{array}$ & $\begin{array}{l}63.3 \\
17.5\end{array}$ \\
\hline 15 & Information sharing behaviour & $\begin{array}{l}\text { Low } \\
\text { Medium } \\
\text { High }\end{array}$ & $\begin{array}{l}13 \\
97 \\
10\end{array}$ & $\begin{array}{c}10.8 \\
80.8 \\
8.4\end{array}$ \\
\hline 16 & Scientific orientation & $\begin{array}{l}\text { Low } \\
\text { Medium } \\
\text { High }\end{array}$ & $\begin{array}{l}13 \\
91 \\
16\end{array}$ & $\begin{array}{l}10.8 \\
75.8 \\
13.4\end{array}$ \\
\hline 17 & Awareness of ICT tools & $\begin{array}{l}\text { Low } \\
\text { Medium } \\
\text { High }\end{array}$ & $\begin{array}{l}24 \\
81 \\
15\end{array}$ & $\begin{array}{l}20.0 \\
67.5 \\
12.5\end{array}$ \\
\hline
\end{tabular}

\section{Profile Characteristics of Farmers}

The findings indicate that nearly three-quarter of the farmers $(72.5 \%)$ were in the old age group of over 46 years, followed by middle age group (19.2\%) of between 36-45 years old while the remaining 8.3 per cent were in the young age group of less than 35 years. This implies that sugarcane farming in the study area is undertaken by older people. A third of the farmers $(28.3 \%)$ had college education level, 25.8 per cent had attained primary education level while those with middle, secondary and higher secondary education levels tied at 10 per cent, 9.2 per cent were illiterate and 6.7 per cent being functionally illiterate.

Regarding socioeconomic activities, most of the farmers $(88.3 \%)$ engaged in agriculture only as their main occupation that entailed crop farming, 6.9 per cent practiced agriculture alongside formal employment in Government or private sectors, while 3.3 per cent were involved in crop farming and animal husbandry and 1.7 per cent were engaged in agriculture and non-agricultural enterprises as such retail and wholesale merchandise selling. The Annual income of a majority of the farmers (81.6\%) exceeded one lakh, 16.7 Per cent had between 5 0001-1, 00,000 rupees while 1.7per cent had less than 50,000 rupees. The high annual income is attributed to the presence of many progressive sugarcane farmers who have adopted improved sugarcane varieties such as CO 012, CO11015, PI 1110 that are early maturing and reliance on irrigation for crop cultivation that guarantees, all year round production.

A third of the farmers (33.3\%) owned between 2.51 to 5.0 acres of land, 26.7 per cent owned 5.01-10.0 acres and 23.3 per cent above 10.0 acres. Three-quarters $(75.8 \%)$ of them had over 20 years farming experience and three-fifth $(61.0$ $\%$ ) cultivated sugar in 5.0 acres of land while over a third (34.2\%) cultivated in 2.51 to 5.0 acres. The farmers had medium level social participation $(62.5 \%)$, mass media exposure (55.8\%), contact with extension agency (69 \%), information seeking behaviour $(67.5 \%)$, innovativeness $(63.3 \%$,) information sharing behaviour $(80.8 \%)$, scientific orientation $(75.8 \%)$ and awareness on ICT tools $(67.5 \%)$.

\section{Knowledge of ICT Tools}

The extent of farmers' knowledge on ICT tools is given in figure.1. 


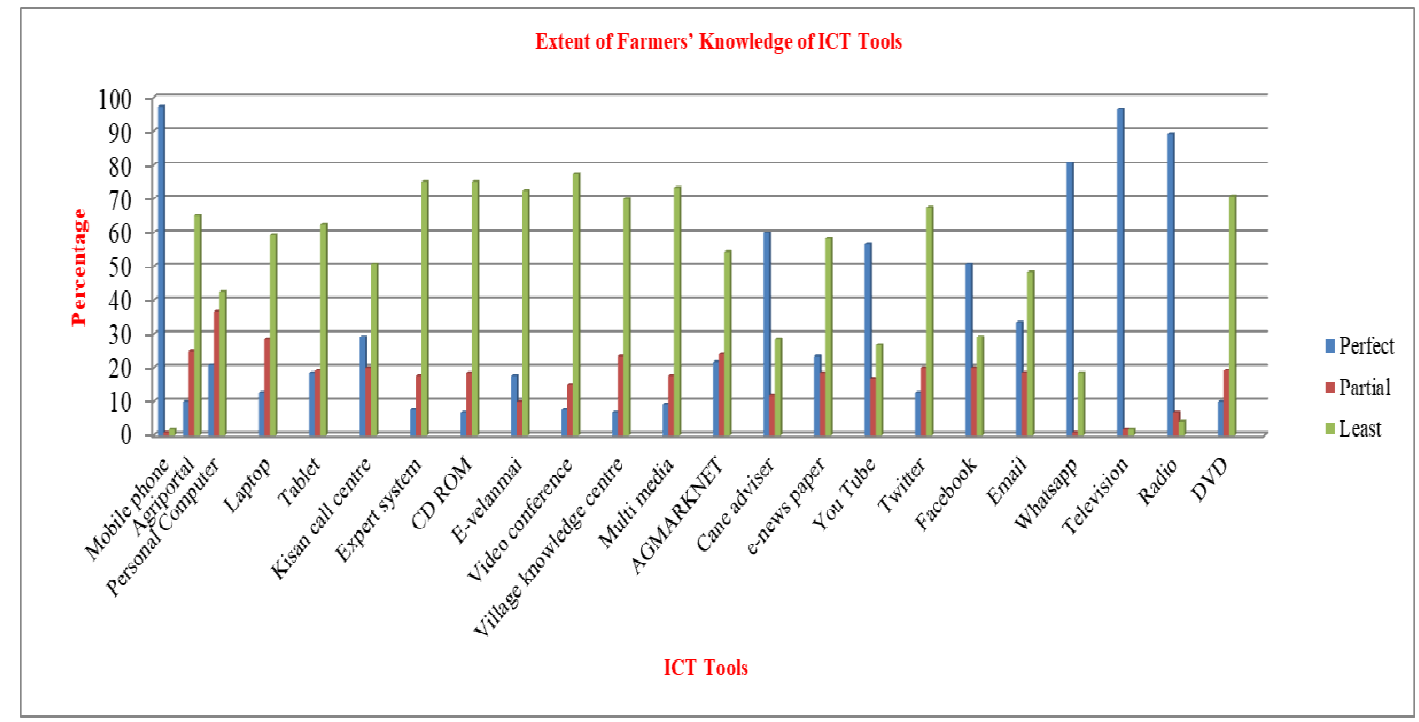

Figure 1: Extent of Farmers' Knowledge on ICT tools

The study sought to find out extent of sugarcane farmers knowledge on ICT tools. Findings indicate that most of the farmers had perfect knowledge on mobile phones (97.5\%), followed by Television (96.7 \%) while Radio had (89.2 \%), Whatsapp $(80.8 \%)$, Cane adviser $(60.0 \%)$ and Facebook $(50.8 \%)$. Slightly over a third of the farmers had partial knowledge on personal computers while 28.0 per cent had partial knowledge on laptops. However, $77.5 \%$ of the farmers had least knowledge on video conferencing, 75.0 per cent each had least knowledge on expert system and CD ROM and 70.8 per cent had least knowledge on digital versatile disc (DVD) as shown in figure 1 above.

\section{Utilization of ICT Tools}

The frequency of farmer's utilization of ICT tools is presented in figure 2.

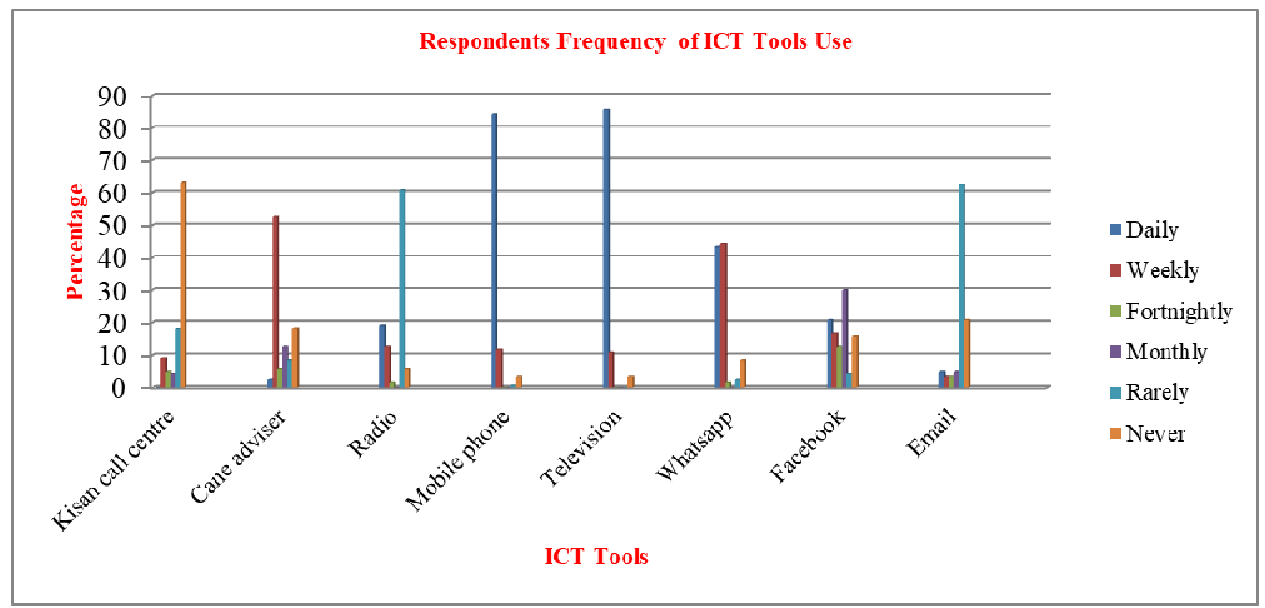

Figure 2: Frequency of Utilization of ICT tools

Regarding ICT tools utilized by sugarcane farmers in accessing information requisite for sugarcane farming, findings revealed that most farmers $(85.8 \%)$ accessed weather forecast information on daily basis through Television, 84.2 per cent through Mobile phone, while 43.3 per cent accessed from Whatsapp and 20.8 per cent through Facebook. Slightly over half $(52.5 \%)$ of the farmers accessed weather forecast information weekly through cane adviser while 43.3percent sourced through Whatsapp on weekly basis. A third of the farmers accessed weather forecast information monthly through 
Facebook while 60.8 per cent rarely used radio to access weather forecast information and 63.3 per cent never used Kisan call centre to inquire weather forecast information.

\section{The Relationship of the Profile of the Farmers with Utilization of ICT Tools}

The study examined relationship of the profile characteristics of farmers with utilization of ICT tools. Findings are summarized in Table 2.

Table 2: Relationship of the profile of the farmers with utilization of ICT $\operatorname{tools}(n=120)$

\begin{tabular}{|c|l|l|}
\hline Variable No. & \multicolumn{1}{|c|}{ Independent variable } & Correlation-coefficient "r" value \\
\hline X1 & Age & $-.211^{* *}$ \\
\hline X2 & Educational status & $.333^{* *}$ \\
\hline X3 & Occupational status & $.027 \mathrm{NS}$ \\
\hline X4 & Annual income & $.154 \mathrm{NS}$ \\
\hline X5 & Size of land holding & $.098 \mathrm{NS}$ \\
\hline X6 & Farming experience & $-.175 \mathrm{NS}$ \\
\hline X7 & Area under sugarcane & $-.023 \mathrm{NS}$ \\
\hline X8 & Experience in Sugarcane cultivation & $.204^{*}$ \\
\hline X9 & Social participation & $.058 \mathrm{NS}$ \\
\hline $\mathrm{X} 10$ & Mass media exposure & $.157 \mathrm{NS}$ \\
\hline $\mathrm{X} 11$ & Contact with extension agency & $.360^{* *}$ \\
\hline $\mathrm{X} 12$ & Training undergone & $.019 \mathrm{NS}$ \\
\hline $\mathrm{X} 13$ & Information seeking behaviour & $.299^{* * *}$ \\
\hline $\mathrm{X} 14$ & Innovativeness & $.053 \mathrm{NS}$ \\
\hline $\mathrm{X} 15$ & Information sharing behaviour & $.358^{* *}$ \\
\hline $\mathrm{X} 16$ & Scientific orientation & $-.009 \mathrm{NS}$ \\
\hline $\mathrm{X} 17$ & Awareness on ICT Tools & $.523^{* *}$ \\
\hline
\end{tabular}

The results indicate that positive and significant correlation existed between use of ICT tools with the independent variables viz., educational status (X2), experience in sugarcane cultivation (X8), contact with extension agency (X11), information seeking behaviour (X13), information sharing behaviour (X15) and awareness on ICT tools (X17). Among the positive and significant variables educational status, contact with extension agency, information seeking behaviour, information sharing behaviour and awareness on ICT were found to be significant at one per cent level of probability whereas experience in sugarcane cultivation was significant at five per cent level of probability. Age (X1) showed negative but significant relationship at five per cent of probability. The correlation values for remaining variables showed nonsignificant association with utilization of ICT tools.

These findings imply that education increases the ability to understand facts, skills, procedures and processes. Educated people tend to have better contact with extension agency and mass media exposure, which in turn improved and increased their access to information. Ordinarily, farmers who have regular contact with extension agency tend to be well informed about emerging and existing farming technologies and practices. This invariably exposes them to better farming knowledge and skills. It can also be deduced that farmers who get information from multiple sources are more likely to have better knowledge and understanding of different aspects of farming

\section{Constraints Faced in ICT Tools Utilization}

The utilization of ICT tools in the study area is satisfactory but farmers face numerous constraints, as shown in fig. 3. 


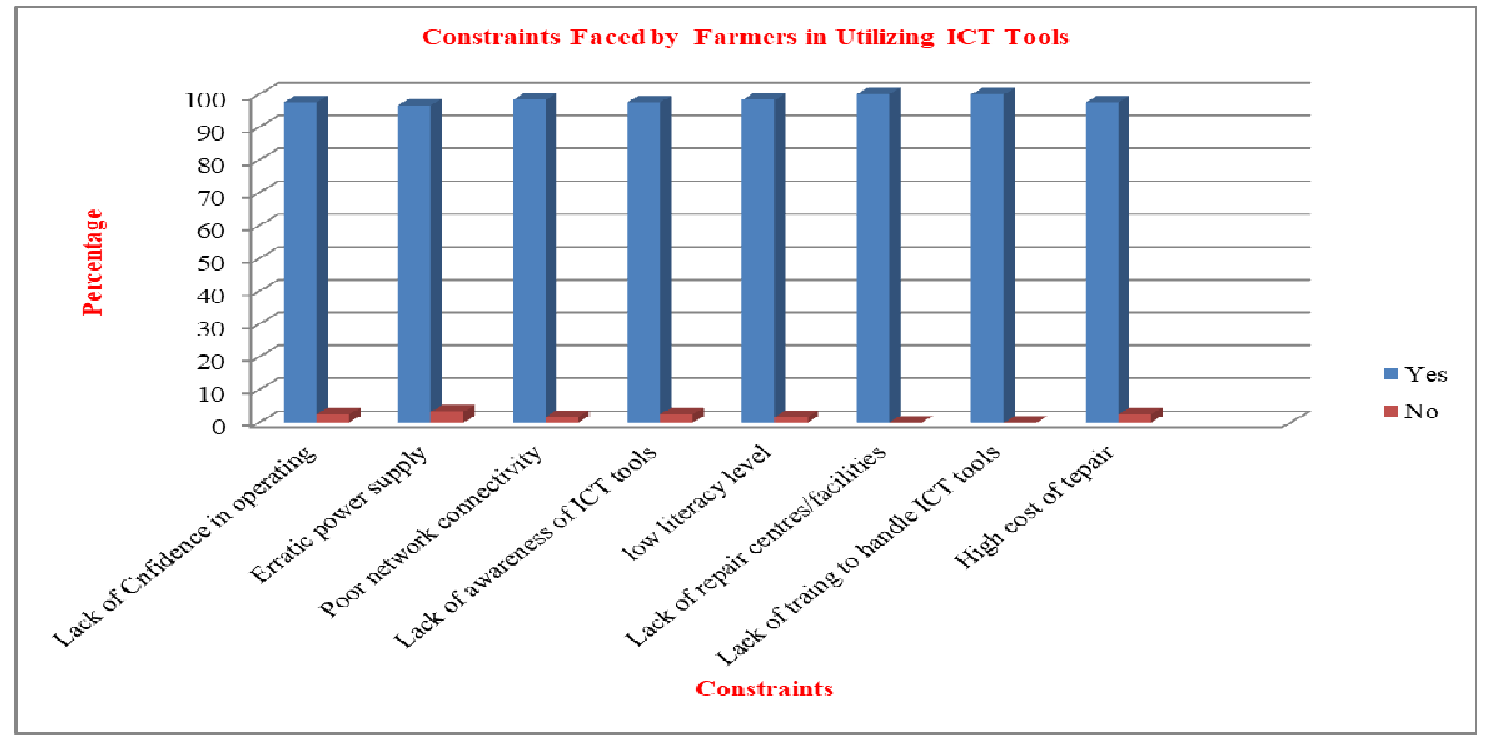

Figure 3: Constraints Faced by Farmers in Utilization of ICT Tools

The finding indicates that all the farmers suggested that the major constraints were lack of training to handle ICT tools and lack of repair centers/facilities within reach, 98.3 per cent each mentioned poor network connectivity and low literacy, 97.5 per cent each indicated lack of awareness, lack of confidence in operating the tools and high cost of repair while 96.7 per cent mentioned erratic power supply.

\section{Suggestion for Improvement}

Farmers suggested some measures that would help to improve the performance of ICT tools, as shown in fig. 4 .

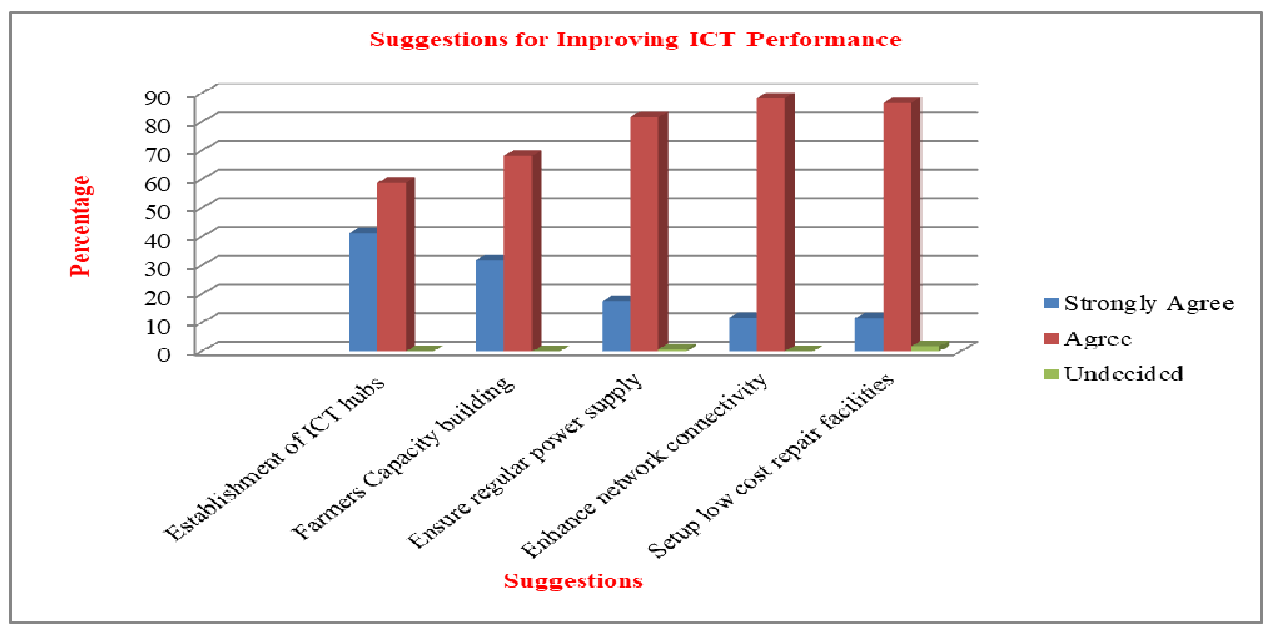

Figure 4: Suggestions for improving efficiency of ICT Tools

Most of the farmers $(88.3 \%)$ agreed that enhancing network connectivity would improve the performance of ICT tools, 86.7 per cent suggested setting up low cost repair centres whereas 81.7 per cent mentioned ensuring regular power supply, 68.2 per cent suggested capacity building of farmers on ICT tools and 58.8 per cent mentioned establishing repair centres in local areas.

\section{CONCLUSIONS}

The finding of the study indicated that most of the farmers were engaged in agriculture for the sole economic activity. Most 
of them were in the old age group with fairly good education and high annual income. A significant proportion of them had over 20 years of farming experience and cultivated sugarcane in land sizes ranging between 5.01 to 10.0 acres. A fairly majority of them, comprising of over half of those involved in the study had close contact with extension agency, mass media exposure and scientific orientation. Most farmers sourced agriculture information on weather forecast, land preparation and crop management and protection and marketing from Mobile phone, Television, Whatsapp, YouTube, Facebook and cane adviser. Radio was least used due to lack of stable frequency modulation (FM) channels in the area. Over two-thirds of the farmers had medium awareness and knowledge of ICT tools as well as utilization of the same. Therefore, farmers knowledge and utilization of ICT tools was noted to be fairly good in the study area.

\section{ACKNOWLEDGEMENT}

The author is highly grateful to the Government of India through Indian Council of Agricultural Research (ICAR) for financial support under third India - Africa Summit fellowship and Kenyan Government through Kenya Agricultural and Livestock Research Organization for the study leave opportunity. The support of the Advisory committee Chairman and entire Department of Agricultural Extension and Rural Sociology, TNAU, Coimbatore, Tamil Nadu is equally appreciated. The writer is also indebted to Ministry of Agriculture officials in the study area and management and staff of Bannari Amman and Sakthi sugar factories located in Erode district.

\section{REFERENCES}

1. Anushree, B. and Madan Mohan, G. (2018): Study of factors governing the use of ICT in Extension deliveries in NorthernEastern Region (NER), India. Amity Journal of Agribusiness., 3 (2): 47-56

2. Anwar, A. (2016): Study on information management behaviour of Rice farmers under collective farming of Kudumbashree mission in Kannur district of Kerala, published M.Sc. (Ag) thesis submitted to Agricultural College, Bapatta-522101, Pp.6-20

3. Food and Agriculture organization (2017): Information and Communication Technology (ICT) in Agriculture. Report to the G20 Agricultural Deputies. Organization of Economic Cooperation and Development (OECD), Pp.ix

4. Felicia, I. and Inioluwa, O. O. (2020): Adoption and utilization of ICT through farmers. NG technology in Ondo State, Nigeria. International Journal of Applied Agricultural Sciences., 6 (1): 7-15.

5. Kansiime, K. M., Abdillahi, K. A., Catherine, A., Manish, S., Arun, J. and Martin, P. (2019): Effectiveness of Mobile Agriadvisory services extension model: Evidence from Direct 2 Farm Program in India., (13): 25-33.

6. Kathlee, F. (2017): Information and Communication Technology Usage by Smallholder Farmers in Rural Mozambique: A case of study of two villages in Central Mozambique. Journal of Rural Social Sciences., 32(2): 1-19.

7. Khushboo, N., Dipak, K.B.and Jahanara. (2018): Knowledge of Farmers towards information and Communication Technology Tools in Pulwart Sharif Block of Patna district of Bihar, India. International Journal of Pure and Applied Bioscience., 6(3): 105-108.

8. Lama, P. (2018): Linking Information and Communication Technology with Youth Farmers in Agriculture, published M.Sc. (Ag) thesis submitted to Purbanchal University., Nepal.Pp 12-18

9. Mohmmed, T.A. (2015): The use of information and communication technology (ICT) in disseminating Agricultural information technology among farmers in Bauchi State, Nigeria, published M.Sc (Ag) thesis submitted to Islamic Online University, Pp 2-22.

10. Neelesh, P. (2017): Role of information and communication technology in Agricultural development: A study of Nabarangpur 
district. Scholedge international journal of Business policy and Government. (4): 24-35.

11. Nenna, M.G. (2014): Assessment of information and communication technology (ICTs) among Cassava farmers in Anambra state, Nigeria. British journal of Research, 3(2): 41-54

12. Ramachandran, T.K. (2018): E-Government initiatives of Government of Tamil Nadu, Pp 2-7

13. Rasheed, S. O. V., Nimisha, M. and Athira. E. (2019): Taking stock and shaping the future conservations on extension, Agricultural extension in South East Asia (AESA). Centre for Research and innovation and Science Policy (CRISP), Pp.313372

14. Tanushree, A. and Prasant, K. P. (2018): Pattern of Digital Divide and Convergence in Access to ICT Facilities among the Indian States. Journal of Infrastructure Development. 10 (1-2): 37-51.

15. Tomar, A., Bhardwaj, N., Verma, A. P. and Sawant, M.N. (2016). Association between Socio-demographic profile and extent of use of ICT among farmers. International Journal of Agricultural sciences and Research., 6(6): 161-166 

